\title{
THE RATE OF PASSAGE OF FOOD IN THE DIGESTIVE TRACT OF RUMINANTS.
}

\author{
Preliminary report. \\ Lauri Paloheimo and Aarne Mäkelä
}

Department of Animal Husbandry, University of Helsinki.

Received 4th October 1952,

Under normal circumstances in man and in farm animals no part of the alimentary tract is ever empty, and in every part there occurs a mixing of the contents so that no sharp boundary exists between the components of successive meals. Paloheimo (4) has shown that in rat in spite of the formation of strata in the stomach, the components of succeeding meals enter into the intestine more or less mixed. It is most likely that the same occurs in other animals with a simple stomach. The process of mixing is most effective in the two first compartments of the ruminant's stomach, and most insignificant in the small intestine and in the rectum.

It is evident that the above mentioned circumstances make it difficult to express in an accurate manner the rate of passage of a certain meal or a portion of a meal in the alimentary tract as a whole or in a certain compartment of it.

The German authors especially express the rate of passage of food residues through the alimentary canal either as the time between the ingestion of a food portion and the first appearance of its residues in the faeces or as the time between ingestion and the last finding of the residues in the faeces. The former expression is quite pertinent as it indicates the maximum velocity at which the alimentary canal can convey the food particles under physiological conditions. The latter expression on the contrary gives only an arbitrary and unclear picture of the delay of food particles, because the disappearance of the last residues of a certain meal occurs very slowly owing to the mixing of different meals. However, this latter mode of expression has only recently been used by MANGOLD (3) in a comparative study on several species of animals. Neither of the above expressions gives any idea of the delay of the bulk of a food portion in the alimentary tract.

Ewing and Smith (2) have tried to determine the average time required for the passage of a certain ration residue through the alimentary tract of a steer. The method is based upon a digestion trial and a subsequent slaughter test, and the 
result was calculated by dividing the food and faecal dry matter content of the alimentary tract by half the sum of the dry matter ingested and excreted per day. Obviously the calculation is based upon the assumption that the average composition of the dry contents of the digestive tract is identical with the weighted average composition of the dry matter of the daily intake and the dry matter of the daily faeces. However, according to our experiments, this assumption does not seem to be valid. Thus the lignin content in the dry matter of the contents of the alimentary tract in 4 cows fed on the same hay varied $13.7-14.8 \%$, while the weighted lignin percentage of the dry matter of the daily intake and the dry matter of the daily faeces was 11.2-11.6. The calculation of the average time required for the passage of undigested food residues according to the method of EwING and SMITH gives results which are about $20 \%$ lower than the average time required for the passage of lignin calculated by our method reported below.

To begin with we tried to examine the delay of food in the rumen of the cow. Our experimental procedure and the calculation of the results are based on the following three propositions which hardly need exposition.

1. During an uniform feeding the daily outgo of dry matter from the rumen is equal to the daily income.

2. During an uniform feeding the dry matter content of the rumen becomes constant.

3. After a period of uniform feeding the dry matter content of the rumen divided by the daily intake of dry matter equals the mean time of retention of a food dry matter particle. ${ }^{1}$

The experiments are carried out with those cows of the Viik experimental farm, that were to be rejected from the herd because of sterility or low production. None of these cows had digestive disorders or defective appetite. Up to the present 19 cows have been used in the experiment and most of them have had hay as their only food. The daily hay rations varied from $3-15 \mathrm{~kg}$. In this report we shall only refer to the experiment with the cows Hilu, Iines, Petturi and Ella which were together in the experiment and accordingly received the same hay as their only food. The daily hay rations which were eaten without remnants were 12.9, 5.0,

Table 1. Data concerning the contents of rumen and the digestive tract as a whole.

\begin{tabular}{|c|c|c|c|c|c|c|}
\hline Cow & $\begin{array}{l}\text { Net weight } \\
\text { of the cow }{ }^{2} \text { ) } \\
\text { kg }\end{array}$ & $\begin{array}{c}\text { Dry matter } \\
\text { of hay eaten } \\
\text { daily } \\
\text { kg }\end{array}$ & $\begin{array}{c}\text { Dry matter } \\
\text { in rumen } \\
\text { kg }\end{array}$ & $\begin{array}{c}\text { Lignin in } \\
\text { the daily } \\
\text { hay ration } \\
\text { kg }\end{array}$ & $\begin{array}{c}\text { Lignin in } \\
\text { rumen } \\
\mathrm{kg}\end{array}$ & $\begin{array}{l}\text { Lignin in } \\
\text { the digestive } \\
\text { tract } \\
\text { kg }\end{array}$ \\
\hline Hilu & 481 & 10.67 & 10.04 & 0.84 & 1.35 & 1.93 \\
\hline Iines & 404 & 4.14 & 5.16 & 0.33 & 0.66 & 1.07 \\
\hline Petturi & 422 & 2.48 & 4.52 & 0.20 & 0.64 & 0.99 \\
\hline Ella & 433 & 2.48 & 6.05 & 0.20 & 0.82 & 1.07 \\
\hline
\end{tabular}

1 Perhaps it would be more exact to use the expression sthe mean time of retention of a dry matter point of the food".

2 The weight of the cow minus the weight of the content of the digestive tract and urine bladder. 
Table 2. Calculated times of retention (days).

\begin{tabular}{|c|c|c|c|c|c|}
\hline \multirow[b]{2}{*}{ Cow } & \multirow[b]{2}{*}{$\begin{array}{c}\text { Dry matter of } \\
\text { hay eaten daily } \\
\mathrm{kg}\end{array}$} & \multicolumn{4}{|c|}{ Mean time of retention of } \\
\hline & & $\begin{array}{l}\text { dry matter } \\
\text { in rumen }\end{array}$ & $\begin{array}{l}\text { lignin in } \\
\text { rumen }\end{array}$ & $\begin{array}{c}\mathrm{N} \text {-free non lignin } \\
\text { organic matter } \\
\text { in rumen }\end{array}$ & $\begin{array}{l}\operatorname{lognin} \text { in } \\
\text { the digestive } \\
\text { tract }\end{array}$ \\
\hline Hilu & 10.67 & 0.94 & 1.60 & 0.79 & 2.29 \\
\hline Iines & 4.14 & 1.25 & 2.02 & 1.04 & 3.27 \\
\hline Petturi & 2.48 & 1.82 & 3.27 & 1.47 & 5.05 \\
\hline Ella & 2.48 & 2.44 & 4.17 & 1.91 & 5.45 \\
\hline
\end{tabular}

3.0 , and $3.0 \mathrm{~kg}$ respectively. After 10 days of uniform feeding the cows were slaughtered and the contents of the different parts of the alimentary tract were measured and examined. Some of the results recorded are presented in table 1.

According to proposition 3 and using the figures of table 1 it is now possible to calculate the average time of retention of a food dry matter particle in the rumen. ${ }^{1}$ It must, however, be considered that some food constituents leave the rumen by way of the blood vessels. As the principle presented in proposition 3 is obviously valid also in regard to the lignin and as the proposition in question must be valid also concerning the whole digestive tract, it is feasible to calculate on the ground of the figures of table 1 the mean time of retention of a lignin particle as well in the rumen as in the digestive tract as a whole. The lignin particle may here be considered as indigestible because it has been experimentally established in this laboratory that the food fraction determined by the method used in these experiments and called lignin passes the digestive tract of ruminants without loss so far as hay is concerned. As also crude protein and ash content of the hay and of the contents of the rumen and other parts of the digestive tract were determined, it was possible to calculate also the $\mathrm{N}$-free non lignin organic matter and its mean time of retention in the rumen. All the above mentioned times of retention are recorded in table 2. The discussion of results will be left to a later paper.

Only few of the data so far published permit calculation of the mean time of indigestible food residues in the digestive tract. PoIJäRvI in his experiments with wethers using chromium oxide as tracer tested the delay of food residues in the digestive tract. From the data presented by PoIJärvI (5) it has been possible to calculate the mean time of retention of the tracer in the alimentary canal. The results of this calculation are found in table 3. Also the excretion curves pertaining to the experiments of BALCH (1) permit an approximate calculation of the average delay of indigestible food residues in the alimentary canal. By way of illustration we have calculated this mean time of delay in the case of cow B in fig. 2 (1.c.) The food of the cow consisted of $7.26 \mathrm{~kg}$ coarse meadow hay and $2.72 \mathrm{~kg}$ of a concentrate mixture. The mean time of retention appeared to be 2.2 days for the stained particles of the hay and 1.5 days for those of the concentrate mixture.

1 The dry matter of saliva has been left without consideration. 
Table 3. Delay of food in the digestive tract of wethers.

\begin{tabular}{ccc}
\hline $\begin{array}{c}\text { Wether } \\
\text { No. }\end{array}$ & Feeding & $\begin{array}{c}\text { Mean time of retention } \\
\text { of the tracer in the } \\
\text { digestive tract (days) }\end{array}$ \\
\hline 1 & $500 \mathrm{~g}$ hay & 2.6 \\
\hline 2 & $1000 \mathrm{~g}$ hay & 2.0 \\
\hline 3 & $300 \mathrm{~g}$ hay \\
$200 \mathrm{~g}$ wheat bran & 3.2 \\
\hline 4 & $600 \mathrm{~g}$ hay & 2.0 \\
\hline
\end{tabular}

It is obvious that excretion curves, such as BALCH has shown, give a clear picture of the delay of indigestible food residues in the digestive tract. The calculation of the mean time of retention, however, gives figures which are useful when the results of different experiments and investigations are compared. Therefore we recommend this calculation in all cases where the experimental data permit its execution. Our experimental method has the disadvantage that the animals used have to be killed at the end of the experiment. Usually, however, suitable animals for such experiments are not difficult to obtain.

\section{REFERENCES.}

(1) Balch, C. C. 1951. Factors Affecting the Utilization of Food by Dairy Cows. 1. The Rate of Passage of Food through the Digerstive Tract. British J. of Nutrition, 4.

(2) Ewing, P. V. and Smith, F. H. 1917. A Study of the Rate of Passage of Food Residues through the Steer and its Influence on Digestion Coefficients. J. of Agric. Res., X.

(3) Mangold, Ernst. 1951. Darmlänge, Durchgangszeit und Durchgangsgeschwindigkeit. Sitzungsberichte der deutschen Akademie der Wissenschaften zu Berlin. Klasse für medizinische Wissenschaften, Jahrg. 1950, Nr. III.

(4) Paloheimo, Lauri. 1939. Über die Verwendung des quantitativen Indikatorverfahrens bei Untersuchung der Nahrungsfortbewegung im Magendarmkanal. Tierernährung 11.

(5) Poijärvi, Ilmari. 1952. Orientierende Versuche über den Einfluss der Futtergrösse auf die Verweildauer der Futterbestandteile im Magen-Darmkanal der Wiederkäuer. J. of the Scientific Agric. Society of Finland, 24. 
S E L OS T US.

\section{RAVINNON KULKUNOPEUS MÄREHTIJÖIDEN RUUANSULATUSKANAVASSA.}

Edeltävä tiedonanto.

\section{Lauri Paloheimo ja Aarne Märelä}

Helsingin Yliopiston Kotieläintieteellinen laitos.

Kirjallisuudessa tavataan lukuisasti mainintoja, jotka ilmoittavat pitkäkö aika kuluu tietyn aterian alkamisesta syödyn rehun ensimmäisten sulamattomien osasten erittymiseen sonnassa, sekä kauanko kestää ennenkuin viimeisetkin osaset ovat poistuneet ruoansulatuskanavasta. Tällaiset tiedot antavat kuitenkin vain kovin puutteellisen kuvan ravinnon tähteiden kulkunopeudesta ruoansulatuskanavassa. Eräät tutkijat, esim. PoIJärvi ja BALCH ovat esittäneet ns. erityskäyriä tai niitä vastaavia lukusarjoja. Tämän tiedonannon kirjoittajat ovat kehittäneet laskutavan, jolla voidaan erityskäyrien perusteella arvioida sulamattoman rehupisteen keskimääräinen viipymisaika ruoansulatuskanavassa. Omat tutkimuksemme ovat suoritetut teuraiksi määrätyillä ruoansulatuksellisesti terveillä lehmillä, joita on 10 viimeisen elinpäivän ajan ruokittu määräaikaisesti määräsuuruisilla heinäannoksilla. Teurastuksen yhteydessä suoritetuilla ruoansulatuskanavan sisällykseen kohdistetuilla tutkimuksilla on hankittu tietoja, joiden avulla on sitten voitu laskea rehun kuiva-ainepisteen keskimääräinen viipymisaika pötsissä sekä ligninipisteen (mikä edustaa rehun sulamatonta osaa) viipymisaika pötsissä ja ruoansulatuskanavassa kokonaisuudessaan. Myös on laskettu typpi- ja ligninivapaan kuiva-ainepisteen keskimääräinen viipymisaika pötsissä. Esimerkkinä on tiedonannossamme esitetty tulokset neljän koelehmän kohdalta taulukossa 2. Ensimmäisessä numerosarakkeessa ilmoitetaan lehmien päivittäin syömä kuiva-ainemäärä (kg), toisessa kuiva-ainepisteen keskim. viipymisaika pötsissä (vrk), kolmannessa ligninipisteen keskim. viipymisaika pötsissä, neljännessä typpi- ja ligninivapaan kuiva-ainepisteen keskim. viipymisaika pötsissä ja viidennessä ligninipisteen keskimääräinen viipymisaika ruoansulatuskanavassa. Vertauksen vuoksi esitetään taulukossa 3 eräitä laskelmia, jotka kirjoittajat ovat suorittaneet PoIJäRven pässeillä suorittamien kokeiden antamien tulosten perusteella: Toisessa sarakkeessa esitetään pässien päivittäinen ruokinta (hay $=$ heinä, wheat bran $=$ vehnän lese), kolmannessa johtoaineena käytetyn rehuun sekoitetun kromioksiidin keskimääräinen viipymisaika (vrk) ruoansulatuskanavassa. BALchin suorittamien kokeiden perusteella on suoritettu samankaltaisia laskelmia. Yhdistetyn heinä-väkirehuannoksen sulamattomien tähteiden keskim. viipymisajaksi saatiin 2.2 vrk. ja sulamattomien väkirehutähteiden 1.5 vrk. 